\title{
Improving Supplier New Product Development Performance: The Role of Supplier Development*
}

\author{
Benn Lawson, Daniel Krause, and Antony Potter
}

Suppliers play an increasingly central role in helping firms achieve their new product development (NPD) goals. The literature implicitly assumes that suppliers are able to meet or exceed the quality standards and technological expectations of the firm, and yet, in practice, suppliers often lack the technological capabilities needed to undertake collaborative NPD. In such situations, a firm may choose to intervene and actively develop the supplier's technological and product development capabilities. We develop a theoretical framework that conceptualizes supplier development activities within interorganizational NPD projects as part of a bilateral knowledge-sharing process: design recommendations, technical specifications, and new technology flow from supplier to the firm, and in turn, the firm can implement supplier development activities to upgrade the supplier's technological capabilities. Antecedents (supplier responsibility, skills similarity, single sourcing strategy) and consequences of supplier development activities (on supplier, product, and project performance) are examined using a sample of 153 interorganizational NPD projects within UK manufacturers. We find broad support for our hypotheses. In particular, we show that the relational rents (in the form of improved product and project performance) attained from supplier development activities in new product development are not achieved directly, but rather indirectly, via improvements in the supplier's creative and technological capabilities. Our results emphasize the importance of adopting a strategic view of the potential returns available from investing in the NPD capabilities of key suppliers, and provide clues about underlying reasons for the suboptimal experiences of many companies' collaborative NPD projects.

\section{Introduction}

A growing body of research indicates involving suppliers in new product development (NPD) can generate substantial improvements in operational, product, and project performance (Lawson, Petersen, Cousins, and Handfield, 2009; Petersen, Handfield, and Ragatz, 2005; Wynstra, von Corswant, and Wetzels, 2010). This involvement may range from simple technical consultation to full design responsibility for components, subassemblies, or systems. However, findings in the literature have been somewhat mixed. While the preponderance of evidence suggests that supplier involvement in NPD is generally beneficial (Johnsen, 2009; Song and Di Benedetto, 2008), others have raised doubts regarding its effectiveness (e.g., Hartley, Meredith, McCutcheon, and Kamath, 1997). The Airbus A380 and Boeing 787 Dreamliner programs, for example, highlight the many challenges and trade-offs in managing suppliers' participation in NPD (Clark, 2006; Tang and Zimmerman, 2009).

Address correspondence to: Benn Lawson, Judge Business School, University of Cambridge, Cambridge CB2 1AG, UK. E-mail: b.lawson@ jbs.cam.ac.uk. Tel: +44-122-376-0587.

* This research was funded by a grant from the Engineering and Physical Sciences Research Council, UK (Grant Number: EP/E003990/1).
Given that the involvement of key suppliers is important to NPD performance, one logical question is to what extent can a firm positively influence a supplier's performance during NPD? The literature has typically assumed that suppliers meet or exceed the quality standards and technological expectations of the firm. But, what if suppliers do not possess the required specialist component knowledge or technological capabilities? Or they bring a strong technology focus but lack the architectural knowledge necessary to incorporate new technologies into the firm's end product? In such situations the firm may need to work to develop their supplier's product development capabilities, before, during, and after they are involved in NPD. To our knowledge, the literature is largely silent on these issues. Our study thus addresses two key research questions: (1) what are the antecedents that influence the extent to which firms invest to develop a supplier's NPD capabilities? and (2) what are the outcomes of these investments during NPD for the supplier, the NPD project, and the performance of the new product?

From a theoretical perspective, Dyer and Singh's relational view (1998) holds that firms and their suppliers can accrue benefits in the form of relational rents when they combine knowledge in novel ways that jointly benefit both parties. For example, a firm may outsource to a supplier a specific aspect of a product or component 
design, and expect, in return, the supplier to develop creative innovations and new technologies that can be integrated into the new product. However, this depiction of supplier involvement is primarily unilateral knowledge sharing of design recommendations, technical specifications, and new technology from the supplier to the firm (Kotabe, Martin, and Domoto, 2003; Lawson et al., 2009; Song and Di Benedetto, 2008). In the present study, we incorporate the flow of knowledge sharing from the firm to the supplier-in the form of supplier development activities that aim to upgrade the supplier's creative and technological contributions to NPD (Modi and Mabert, 2006; Wagner and Krause, 2009). Thus, we investigate the nomological network of factors that may encourage firms to actively manage the performance of suppliers during NPD.

In doing so, a number of gaps in the extant literature are addressed. First, to date, the literatures on supplier development and supplier involvement have evolved largely in parallel, and there is a deficiency of research with respect to supplier development activities in NPD (Johnsen, 2009; Wagner and Krause, 2009). To address this gap, we propose a model in which the supplier's engineering responsibility in the NPD project, skill similarity between the firm and supplier, and the use of a

\section{BIOGRAPHICAL SKETCHES}

Dr. Benn Lawson is a senior lecturer in operations management at Cambridge Judge Business School, University of Cambridge, UK. He received his Ph.D. from the University of Melbourne. His research interests are in global production networks, and the intersection of supply chain management and new product development. His work has been published in outlets such as Journal of Product Innovation Management, Journal of Operations Management, Human Resource Management, and Journal of Supply Chain Management.

Dr. Daniel Krause is professor of operations and supply chain management in the College of Business at Colorado State University. He received his Ph.D. and M.B.A. degrees from Arizona State University, Tempe, AZ, USA. His research interests include interorganizational relationships, supplier development, supplier involvement in new product development, and sustainability efforts in supply chains. His publications have appeared in several journals including Sloan Management Review, Decision Sciences, Journal of Business Logistics, Journal of Operations Management, Journal of Supply Chain Management, and International Journal of Production Research.

Dr. Antony Potter is a lecturer in operations management at Manchester Business School, University of Manchester. He received a Ph.D. from the University of Sheffield. His research interests focus on supplier involvement in new product development, supply chain risk, lean production systems, and the evolution of clusters and networks. He has published in Journal of Product Innovation Management, International Journal of Operations and Production Management, Trends in Food Science and Technology, Journal of Economic Geography, and Regional Studies. single supplier are associated with supplier development activities in NPD. Second, research on supplier development has primarily been concerned with improving a supplier's operational performance in areas such as quality, cost, delivery, and flexibility (Krause, Handfield, and Tyler, 2007; Wagner and Krause, 2009). By contrast, conducting an NPD project across interorganizational boundaries differs from typical day-to-day operational requirements between supply chain parties as the most important supplier tasks revolve around creative and technological contributions (Carson, 2007; Loch and Kavadias, 2008; Ragatz, Handfield, and Scannell, 1997). Exploring the relationship between a firm's efforts to improve a supplier's NPD capabilities and subsequent supplier task performance (their creativity and technology contributions) is a key focus of the paper.

Third, we examine the interrelations among performance outcomes, explicitly considering the effect of supplier development (SD) in NPD (SD-NPD) on supplier's task performance (in terms of creativity and technology contributions), project performance, and new product advantage. Finally, this is one of the first studies to take a holistic view of the relational dynamics between the firm's effort directed at developing its suppliers' technological capabilities, and in turn, the supplier's creative and technological contribution to the NPD project.

The remainder of the paper is structured as follows. First, we examine the literature relating to supplier involvement and supplier development in the context of interorganizational NPD. Subsequently, we develop hypotheses, and describe our methodology and analysis. Finally, we discuss the results of our analysis and provide implications for decision-makers and future research.

\section{Literature Review}

\section{Supplier Involvement in New Product Development}

Many well-known firms such as Honda, Chrysler, and Toyota have implemented supplier involvement practices that have transformed their operations and supply chains (Sobrero and Roberts, 2002). In particular, supplier involvement is regarded as one of the reasons why Toyota was able to launch new products faster, with shorter development times, and lower development costs (Dyer and Ouchi, 1993; Liker, Kamath, Wasti, and Nagamachi, 1996). Over the past 20 years, a large number of studies have examined the antecedents, characteristics, moderators, and performance outcomes associated with supplier involvement in product innovation (Clark and Fujimoto, 1991; Lawson et al., 2009; Petersen et al., 2005; Ragatz 
et al., 1997). Various dimensions of supplier involvement have been investigated, such as supplier selection (Emden, Calantone, and Droge, 2006), joint problem solving cycles (Clark and Fujimoto, 1991), timing of involvement (Swink, 1999), decision-making (Petersen, Handfield, and Ragatz, 2003), team structures (Ragatz et al., 1997), knowledge sharing (Lawson et al., 2009), and supplier engineering responsibility (Liker et al., 1996). Supplier involvement has been found to have a positive effect across a range of different performance outcomes, including reduced material costs, improved material quality, shorter development times, lower project costs, enhanced product functionality, improved product manufacturability, lower manufacturing costs, and access to supplier technology (Handfield, Ragatz, Petersen, and Monczka, 1999; Lau, Tang, and Yam, 2010; Ragatz et al., 1997).

However, there is also evidence that supplier involvement has a number of disadvantages (Johnsen, 2009; Primo and Amundson, 2002), including greater bureaucracy (King and Penleskey, 1992), additional coordination time (Eisenhardt and Tabrizi, 1995), and lower efficiency (Littler, Leverick, and Bruce, 1995). In particular, debate remains over whether supplier involvement helps to shorten or lengthen the development time of a new product (Ragatz et al., 1997); and whether supplier involvement helps to decrease or increase product development costs (von Corswant and Fredriksson, 2002). Consequently, recent research attention has focused on determining which management practices and capabilities decisionmakers within the firm should utilize in order to successfully integrate suppliers into their NPD project and achieve superior product innovation outcomes.

Capabilities are "complex bundles of skills and collective learning, exercised through organizational processes that ensure superior coordination of functional activities" (Day, 1994, p. 38). For example, the ability to effectively manage business-to-business relationships has been identified as a critical capability (Jarratt, 2004). In the present paper, we identify two distinct organizational-level capabilities in supplier involvement: first, the capabilities of suppliers to contribute knowledge, technology, and various skill sets to the NPD process, and second, the capability of customer firms to integrate suppliers into the NPD process. The former includes the suppliers' ability to provide technical and production expertise, to move quickly from providing a prototype to volume production, and to incorporate new technologies into the subassemblies and component parts they make and deliver to their customer. The latter includes the ability of the firm to manage the quality of their suppliers' NPD performance and to step in to help suppliers when needed. For example, suppliers and their representatives often lack the project management skills required to be effective contributors to NPD teams. Working as part of an interorganizational NPD team with people across different companies and skill sets, while meeting challenging time-related and technical deadlines, can be challenging for the supplier, and so may form part of the supplier development effort.

\section{Developing a Supplier's New Product Development Capabilities}

Ford Motor Company undertook supplier development as far back as the early 1900s (Seltzer, 1928), though it wasn't until the 1980s and 1990s that greater attention was paid to developing the operational capabilities of suppliers (Krause, Handfield, and Scannell, 1998; Leenders, 1966). Krause et al. (1998, p. 40) define supplier development as "an effort by an industrial buying firm to improve the performance or capabilities of its suppliers." Previous research has focused on the antecedents of supplier development (Krause, 1999), supplier development goals (Wagner and Krause, 2009), the process of supplier development (Hartley and Choi, 1996), reactive and proactive supplier development (Krause et al., 1998), supplier development practices (Modi and Mabert, 2006), and the performance outcomes associated with supplier development (Dyer and Hatch, 2006). Other research identified four different supplier development strategies including competitive pressure, evaluation and certification systems, incentives, and direct supplier development (Krause, Scannell, and Calantone, 2000).

Greater involvement of suppliers in NPD in recent years has led firms to consider how to rectify deficiencies and develop further their suppliers' capabilities in product design. A firm may undertake direct supplier development with the intention of developing a supplier's new product development capabilities within a particular NPD project by sharing technological knowledge and organization routines (Modi and Mabert, 2006), helping design production processes for the new product, and sending employees to the supplier's facilities. Such activities are often required because design errors, quality defects, and technical glitches are built into the new product during the early phases of the NPD cycle, and frequently originate from the suppliers that are involved in the NPD project (Hoopes, 2001; Koufteros, Rawski, and Rupak, 2010; Rauniar, Doll, Rawskic, and Hong, 2008). A proactive approach to supplier development during product development can prevent such quality defects occurring within the supply chain before the new product is launched into the market (Krause et al., 2007; 
Wagner, 2006), as well as facilitate joint problem solving, knowledge sharing, commitment, and relational trust.

While firms increasingly educate and develop suppliers selected for involvement in their NPD projects, empirical evidence on the effectiveness of such practices is sparse. One reason for the mixed results for the effects of SD-NPD may be that research has not fully investigated the education and development activities that take place between a firm and supplier during NPD. More specifically, research has yet to explore the extent to which firms allocate resources to supplier development efforts before or during the involvement of suppliers in NPD. Furthermore, firms may not be synchronizing their supplier development and supplier involvement practices, and in particular, may not be focused on supplier creativity and innovation as important determinants of NPD success. For example, many firms involve suppliers in NPD without thinking proactively about how to improve supplier capabilities to solve technical glitches that frequently occur during NPD (Koufteros et al., 2010; Rauniar et al., 2008). Instead, firms often rely on a reactive supplier development approach-after the start of production-once they find their supplier's performance lacking. The experience of Boeing's 787 Dreamliner program would seem indicative of just such an approach. This effort may also be necessary especially when there are few alternative suppliers to switch to and the supplier provides a strategic item.

\section{Theoretical Framework}

Given that supplier involvement efforts vary in terms of their success in meeting NPD goals, the present research focuses on the efforts of firms to increase the capabilities of suppliers during NPD and the effects on performance. Our model first examines the antecedents of supplier development and education activities in NPD. Specifically, do the level of supplier responsibility, supplier skills similarity, and the use of a single-sourcing strategy influence firm decisions to proactively develop suppliers? These factors are among the key strategic decisions in forming a supplier involvement in NPD sourcing strategy (Handfield et al., 1999; Roy and Sivakumar, 2012; Van Echtelt, Wynstra, Van Weele, and Duysters, 2008). Second, we investigate the effect of supplier development and education activities on elements of NPD performance. Each party may bring complementary capabilities to NPD. For example, the supplier may bring technical expertise, and the buyer may bring project management expertise and other technical knowledge (Dyer and Singh, 1998). However, the majority of the extant literature does not differentiate between the impact of supplier development activities during NPD on different organizational outcomes (Krause et al., 2007). As shown in Figure 1, we propose that SD-NPD is positively related to supplier task performance, in the form of the supplier's creative and technological contributions, which in turn enhances the project performance and new product advantage achieved.

\section{Supplier Responsibility}

Previous studies have found that project and product performance can be enhanced when suppliers are given more engineering responsibility within collaborative NPD projects. Liker, Kamath, and Wasti (1998), for example,

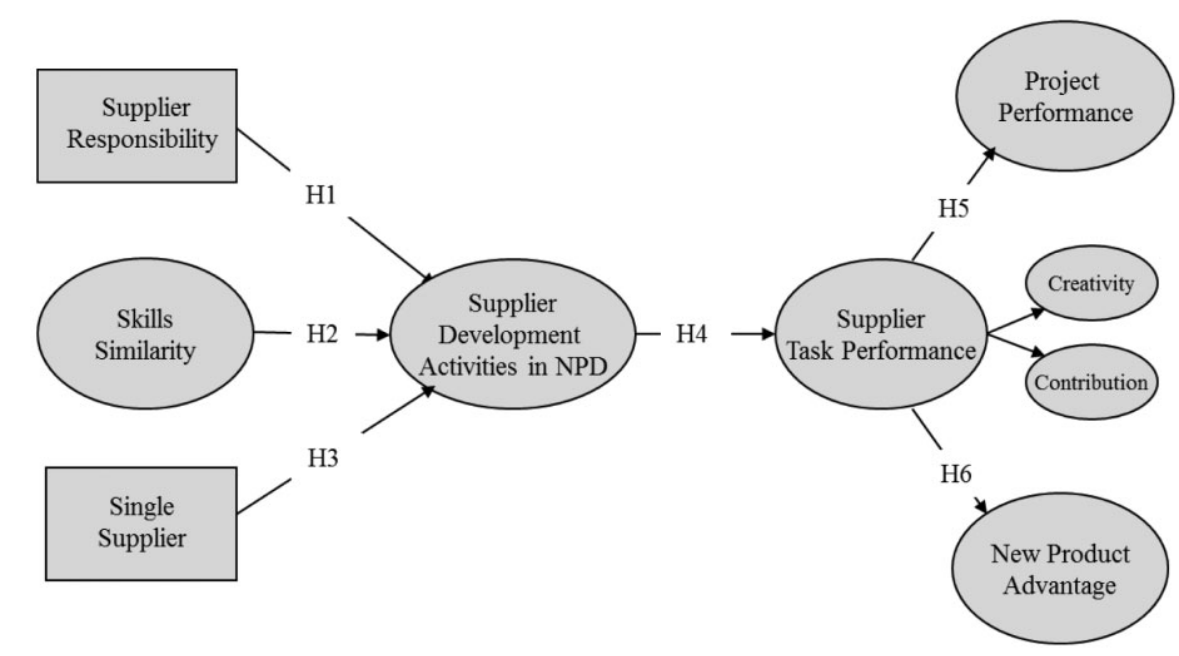

Figure 1. Theoretical Framework 
in a survey of automotive component suppliers found greater contributions of suppliers to cost reduction, quality improvement, and design for manufacturability while in their seminal study, Clark and Fujimoto (1991) analyzed product development processes and performance in the automotive industry showing, inter alia, that Japanese automotive firms delegated significantly more responsibility to their suppliers than U.S. and European producers. The general consensus is that NPD projects can experience superior performance when greater responsibility for NPD activities and decision-making is devolved to suppliers (Bonaccorsi and Lipparini, 1994; Swink, 1999). From a managers' perspective, one of the primary motivations for allowing suppliers to take on greater responsibility is to reduce the cost, development time, and risk of NPD (Koufteros et al., 2010; Liker et al., 1998). Such motivations underlie recent examples of outsourcing responsibilities for product and process design to suppliers, such as Toyota, Boeing's 787, and Airbus A380.

However, suppliers that have been allocated the greatest NPD responsibility must meet quality, technical, design, time, and managerial expectations. Therefore, firms that are convinced SD-NPD is a good investment will carefully consider how to allocate those resources to increase the probability of NPD success. Dyer and Singh (1998) note that a firm transferring know-how to another firm must have incentives to incur the cost of making such a transfer. In this case, the firm is incentivized to invest in supplier development because of the significance of the supplier's role in the NPD project and to increase NPD success. Investing in supplier development helps ensure that standards, procedures, and performance outcomes within NPD are high, for example, by reducing the risk that quality defects, technical mistakes, design errors, and glitches will be designed or built into the new product.

H1: There is a positive relationship between the proportion of engineering responsibility delegated to the supplier and the level of supplier development activities undertaken during the NPD project.

\section{Skills Similarity}

Within a firm's supply base, there is likely to be a portfolio of technical skills: some suppliers will have compatible technical skills with the firm, while other suppliers will be specialists in different skills and knowledge pools (Bensaou and Anderson, 1999). Dyer and Singh (1998) argue that firms generate relational rent by leveraging the distinct resources of each party. In their study of 253 suppliers to the equipment industry, Mesquita, Anand, and Brush (2008) provide support for this assertion showing partnership exclusive performance results in greater performance improvements. Thus, we argue that collaborative NPD projects provide an opportunity for firms to build distinctive supplier resources.

In the context of collaborative NPD, skills similarity occurs when the supplier's technical work shares similarities with the firm's activities, when employees of the two firms have similar training and technical backgrounds, and when the firm is successful in the same technological field as the supplier (Carson, 2007). Knowledge sharing and the transfer of technological routines across interorganizational boundaries are often facilitated when the supplier and firm share similar technological capabilities and skills (Handfield et al., 1999; Kotabe et al., 2003). Hence, as the firm and its supplier have increasing overlap in their respective skill sets, the returns from supplier development and education activities are likely to decrease. As internal resource constraints limit the ability of a firm to develop all their suppliers, they therefore target supplier development at dissimilar suppliers that represent the greatest strategic risk. Following Dyer and Singh (1998), we propose that in recognizing the distinct and similar resources of each party (Mesquita et al., 2008), firms will be less likely to invest in SD-NPD for suppliers with skill sets similar to their own.

\section{H2: There is a negative relationship between skills simi- larity and the level of supplier development activities undertaken during the NPD project.}

\section{Single Sourcing}

An important way in which decision-makers manage collaborative NPD projects is via the type of sourcing strategy used (Liker et al., 1996). Single sourcing involves the deliberate selection of one supplier, even though multiple suppliers are available. Using a single supplier to provide a technological solution or to develop a subassembly for an NPD project may be more efficient in terms of managing the relationship and minimizing project complexity. In contrast, multiple sourcing, with two or more suppliers, may increase competition among suppliers and reduce supply chain risks. Costantino and Pellegrino (2010), for example, adopt a real options approach to modeling the value of multiple sourcing for managing supplier default risk. However, relying upon market governance may also constrain the ability of both parties to conduct joint activities in collaborative NPD (Krause et al., 2000). Further, developing the capabilities of 
multiple suppliers, instead of a single supplier, of a particular item can be costly and has the potential to increase complexity and development times (Primo and Amundson, 2002).

To improve product quality and lower costs, Deming (1986) argues that firms should build long-term collaborative relationships with a single supplier for an item and invest in supplier development. Using agency theory, Richardson and Roumasset (1995) construct an analytical model showing support for Deming's (1986) assertions that sole sourcing is preferable where a high level of specific investments are required, such as collaborative NPD. However, single sourcing can also increase the firm's dependence on the supplier, raise the risk of supplier opportunism, increase switching costs, and lock-in obsolete technologies (Ramsay, 1990). Thus, given the multi-faceted importance of a single-source supplier's position in an NPD project, firms may engage in supplier development and education activities to achieve transparency, manage risk, and minimize glitches. Following Dyer and Singh's (1998) relational view, we propose that the use of supplier development enhances the benefits of single sourcing, while simultaneously minimizing its risks.

H3: There is a positive relationship between the use of a single-supplier strategy and the level of supplier development activities undertaken during the NPD project.

\section{Supplier Development Activities in NPD and Performance Effects}

When a firm develops a supplier during the process of NPD, it enhances the ability of the supplier to generate creative innovations tailored to the firm's needs. That is, making relation-specific investments through supplier development and thus combining resources in unique ways may create idiosyncratic interfirm linkages that produce relational rents and, ultimately, competitive advantage (Dyer and Singh, 1998). During the process of supplier development in NPD, managers may conduct site visits, provide technological and project management knowledge, and train supplier's employees, aimed at improving the supplier's creativity and innovation capabilities, that is, the supplier's task performance (Carson, 2007). When firms develop their suppliers, they increase the stock of new knowledge within the supplier's NPD team, which may lead to greater creativity and technological innovation by the supplier (Amabile, 1998). For example, if the firm provides project management knowledge of the most effective and efficient ways to develop creative innovations, then the supplier may become more capable at product development.

\section{H4: There is a positive relationship between supplier development activities undertaken during the NPD project and the supplier's task performance.}

As each firm specializes in its own core competency along a supply chain, its NPD activities also become specialized in a niche product group, market, industry, technology, subassembly, or system (Loch and Kavadias, 2008). This trend has seen many firms outsource specific NPD activities and build integrated problem solving cycles in order to access suppliers' unique skills and creativity. Consequently, firms have become increasingly reliant on their suppliers to generate innovations and creative solutions, which must then be integrated into the new product (Leonard-Barton, 1995). As Grant (1996) argues, firms can therefore generate a new product advantage by being more successful at knowledge integration with suppliers, especially if they can access creative innovations that lead to a first mover advantage (Lieberman and Montgomery, 1988). Further, when suppliers have higher levels of creativity and innovation capabilities, they are more likely to develop novel solutions, features, and performance attributes, thereby enabling the new product to attain a unique market advantage (Hoopes and Postrel, 1999).

\section{H5: There is a positive relationship between a supplier's task performance (creativity and technological contribu- tion) and new product advantage.}

Little research has explored the impact of supplier task performance-conceptualized in terms of creativity and technological contribution-on project performance when suppliers are involved in NPD. Previous research has shown that suppliers' technological capabilities are an important determinant of project effectiveness and product success (Hoopes and Postrel, 1999; Takeishi, 2001). By upgrading a supplier's creative and innovative performance, firms are likely to find that the supplier can generate novel solutions to technical errors, design defects, and glitches, which enables the technical goals, quality targets, schedules, and costs for the project to be met (Koufteros et al., 2010). Hoopes and Postrel (1999), for instance, argue that supplier involvement and interfirm knowledge sharing can help to solve causally ambiguous technical glitches within NPD, which are an important source of project delays and cost overruns.

H6: There is a positive relationship between a supplier's task performance (creativity and technological contribution) and NPD project performance. 


\section{Research Design}

\section{Sample Characteristics}

The present study is part of a broader research effort to investigate supplier involvement in NPD. Other papers drawing on this data set include Lawson and Potter (2012), Potter and Lawson (2013) and Lawson, Tyler, and Potter (2014). Using a database on R\&D-intensive firms maintained by the UK Department of Trade \& Industry, we survey 1700 medium-to-large manufacturing firms. The firm's Standard Industry Classification (SIC) industry code and plant size (minimum 100 employees) was used to screen the database. Each firm was also telephoned prior to distributing the survey to confirm the selection criteria and identify the most appropriate respondent. At this stage, 204 firms did not meet the selection criteria and were removed from the sample.

Surveys were received from 160 respondents, though seven were unusable due to incomplete responses. The final sample contained 153 firms, giving an effective response of $10.3 \%$. Respondents originated from a variety of industries, including electrical (35.3\%), aerospace $(14.4 \%)$, chemicals $(11.8 \%)$, pharmaceutical $(10.4 \%)$, automotive $(8.5 \%)$, and general manufacturing (11.1\%). Eleven percent of firms did not provide details of their industry classification. Respondents included purchasing managers (38.5\%), operations managers (19.6\%), R\&D managers (17.0\%), and procurement directors $(15.6 \%)$. They had an average of 9.56 years of experience in their industry, and following the preliminary screening, which confirmed familiarity with an NPD project in which a supplier was involved, we have confidence that our respondents are knowledgeable about the issues examined. No significant mean differences were detected between groups of respondents, or across functional departments. The sample characteristics are presented in Table 1.

\section{Survey Administration}

The unit of analysis is a single dyadic relationship between the buyer firm and a supplier that had been involved in a collaborative NPD project completed within the last 3 years. Respondents were further instructed to select a supplier that had provided a critical component or subassembly into the firm's end product. As an additional validation check, we also asked respondents their level of knowledge of the supplier relationship and NPD project, using a Likert scale of 1 to 7, where 7 represented "extensive knowledge." A mean response of 5.8 (out of 7) pro-
Table 1. Sample Characteristics

\begin{tabular}{lcc}
\hline (1) Industry & Frequency & $\%$ \\
\hline Aerospace & 22 & 14.4 \\
Automotive & 13 & 8.5 \\
Chemicals and chemical products & 18 & 11.8 \\
Electronic and industrial equipment & 54 & 35.3 \\
General manufacturing & 17 & 11.1 \\
Pharmaceutical & 16 & 10.4 \\
Not reported & 13 & 8.5 \\
Total & 153 & 100 \\
\hline (2) Business Units' Annual Sales & Frequency & $\%$ \\
\hline Under £25M & 52 & 34.0 \\
£25-£50M & 18 & 11.8 \\
$£ 50-£ 100 M$ & 15 & 9.8 \\
$£ 100-£ 250 M$ & 17 & 11.1 \\
$£ 250-£ 500 M$ & 15 & 9.8 \\
Over £500M & 20 & 13.1 \\
Missing & 16 & 10.5 \\
Total & 153 & 100.0 \\
\hline (3) Titles & 153 & $\% .1$ \\
\hline Operations manager & Frequency & 100.0 \\
R\&D manager & 30 & 19.6 \\
Purchasing manager & 26 & 17.0 \\
Procurement director & 59 & 38.5 \\
Missing & 24 & 15.7 \\
Total & 14 & \\
\hline & & \\
& & \\
& &
\end{tabular}

vides confidence that respondents were knowledgeable regarding the items under investigation.

Semi-structured interviews were carried out with 10 purchasing managers, project managers, and design engineers to refine the survey and constructs being examined. Further pilot testing of the survey instrument was conducted with 10 additional managers and 6 academic experts. Following the phone call, each respondent was sent the survey, along with a covering letter providing background information. Dillman's (2000) procedures were followed in an effort to maximize the response rate, including offering a summary of the findings, the option to return via return post or the Internet, and sending a reminder postcard after 2 weeks (Forza, 2002). One round of follow-up telephone calls was also made to nonresponders after 6 weeks.

Additional tests were carried out to identify potential areas of concern in relation to response bias, such as between early and late respondents (Armstrong and Overton, 1977). No significant differences were identified. Further representative checks using Pearson's chisquare tests also identified that the sample is broadly representative of the population of firms (Greene, 2002). 


\section{Operationalization of Variables}

All constructs were drawn from the extant literature. Items were assessed on a Likert scale ranging from 1 "strongly disagree" to 7 "strongly agree." Further details of these measures are provided in the Appendix.

New product advantage. The scale developed by Song and Parry (1997) was adopted, with respondents asked to assess their firm's new product compared to those of competitors' products in terms of unique features, technical performance, quality, enabling customers to do something they could not presently do, and meeting customers' needs.

Project performance. A modified version of Petersen et al. (2003) was used to assess the performance of the NPD project. The five-item construct examined whether, relative to the firm's internal goals, the project had met quality standards, technical objectives, schedule targets, budgeted cost targets, and project goals. A seven-point Likert scale anchored at $1=$ "much worse" to $7=$ "much better" was used.

Supplier task performance. Following Carson (2007), this factor was broken into two subfactors assessing supplier creativity and technology contribution. The creativity subfactor asked about the supplier's contribution in terms of providing new knowledge, new discoveries, and the level of creativity. The technology contribution subfactor asked respondents to characterize the supplier's anticipated technology contribution to the NPD project in terms of its effect on competitiveness, functionality, and profitability of the new product. This ensures the construct reflects both the creativity and the broader value of the technology provided by the supplier.

Supplier development activities in NPD (SD-NPD). A scale previously developed by Krause et al. (2000) was adapted to an NPD context. Five items measured the degree to which firms were directly involved in the supplier's product development activities, visited the supplier's facilities to help them improve their product development performance, provided technological knowhow, aided in the design of production processes for the new item, and provided project management know-how during product development.

Supplier responsibility. The approach of Liker et al. (1996) was adopted asking respondents to indicate the percentage of total engineering hours for the new product attributable to this specific supplier.

Skills similarity. A four-item scale was adapted from Carson (2007), with respondents asked to consider the similarity of the firm's task-related skills to those of the supplier at the outset of the project (to avoid confounding effects of skills learned during the project). Items assessed the competencies embedded at the firm unitlevel with regards to the similarity of the supplier's technical work to that regularly done by the firm, to the firm's most important products, to the firm's technical background, and to the firm's ability to successful perform the type of work the supplier was doing.

Single supplier sourcing. Respondents were asked to quantify the percentage of their total purchases of the particular item provided by the supplier; and then how many suppliers in total were used. The variable was binary coded as single supplier sourcing set to 1 , otherwise 0 .

Control variables. Relationship length was controlled for due to its likely influence on the extent of supplier development activities conducted by the firm because of familiarity with the supplier. Component importance was also included, coded as 1 or 0 , depending on whether the supplier provided a subassembly to the firm (Liker et al., 1996). Finally, a binary variable of technological newness controlled for the need to undertake supplier development activities and the extent of product advantage gained due to the degree of "radicalness" of the end new product.

\section{Data Analysis}

\section{Confirmatory Factor Analysis}

A two-step process of analysis, with AMOS 19.0 (IBM SPSS Amos, Version 19.0, IBM Corp., Armonk, NY, USA), was employed to test our hypotheses (Anderson and Gerbing, 1988). Confirmatory factor analysis (CFA) was undertaken to investigate the validity and unidimensionality of the constructs. One of the loadings within each of the constructs was set to a value of 1 , and low factors loadings, high residual values, and modification indices examined to detect potential issues. Three items, one each from new product advantage, project performance, and supplier development were removed from the analysis due to low loadings. Table 2 outlines the results from this analysis, including the loadings and error terms of the manifest variables onto each latent variable. One 
Table 2. Confirmatory Factor Analysis

\begin{tabular}{|c|c|c|c|}
\hline Factors and Items & Standardized Loading & Error Term & $t$-value \\
\hline \multicolumn{4}{|c|}{ New product advantage } \\
\hline NA1 & .90 & - & - \\
\hline NA2 & .93 & .06 & 16.91 \\
\hline NA3 & .83 & .06 & 14.04 \\
\hline \multicolumn{4}{|l|}{ Project performance } \\
\hline PP1 & .90 & .14 & 9.40 \\
\hline PP2 & .84 & .12 & 9.06 \\
\hline PP3 & .61 & .16 & 6.91 \\
\hline PP4 & .69 & - & - \\
\hline \multicolumn{4}{|c|}{ Supplier task performance (creativity and contribution) } \\
\hline CR1 & .73 & - & - \\
\hline $\mathrm{CR} 2$ & .89 & .11 & 11.10 \\
\hline CR3 & .93 & .11 & 11.50 \\
\hline $\mathrm{CO} 4$ & .87 & - & - \\
\hline $\mathrm{CO5}$ & .72 & .08 & 9.17 \\
\hline $\mathrm{CO6}$ & .69 & .09 & 8.62 \\
\hline \multicolumn{4}{|c|}{ Supplier development in new product development } \\
\hline SD1 & .76 & - & - \\
\hline SD2 & .87 & .11 & 10.33 \\
\hline SD3 & .80 & .11 & 9.73 \\
\hline SD4 & .68 & .11 & 8.28 \\
\hline \multicolumn{4}{|l|}{ Skills similarity } \\
\hline SS1 & .86 & .11 & 9.75 \\
\hline SS2 & .85 & .11 & 9.69 \\
\hline SS3 & .70 & .10 & 7.99 \\
\hline SS4 & .73 & - & - \\
\hline
\end{tabular}

and two-factor solutions for supplier task performance were also examined, with a chi-square difference test indicating that the second-order factor produced significantly better fit to the data than a one-factor solution $\left(\Delta \chi^{2}[2]=42.6, p<.01\right)$.

Harman's one-factor test was used to examine potential common method bias (Podsakoff, MacKenzie, Lee, and Podsakoff, 2003). A principal component factor analysis was conducted on all constructs, with factor 1 (largest factor) accounting for $24 \%$ of the variance. No single factor emerged, nor did one factor account for most of the variance, indicating that common method bias may not be a serious problem in the data.

Model fit was examined using four measures: the chisquare test, the comparative fit index (CFI), the TuckerLewis Index (TLI), and the root mean square error of approximation index (RMSEA) (Gerbing and Anderson, 1992). The fit of the CFA to the data was satisfactory $\left(\chi^{2}[177]=320.36, p=.00 ; \quad \mathrm{CFI}=.92 ; \mathrm{TLI}=.91 ;\right.$ and RMSEA $=.073$ ). A number of procedures were then followed to check for convergent validity (Bagozzi and Yi, 1988) and discriminant validity (Anderson and Gerbing, 1988; Fornell and Larcker, 1981). The convergent validity of the scales (extent to which the measurement items reflect a common underlying construct) was supported, with estimated coefficients of all indicators being significant $(t>2.0)$. The average variance extracted (AVE), which measures the variance captured by the indicators relative to measurement error, was also greater than the .50 minimum necessary to justify the use of a construct (Hair, Anderson, Tatham, and Black, 1998). Composite reliability values also provide a further assessment of internal consistency. A minimum value of .70 is recommended as it indicates that around .50 of the variance (the squared loading) can be attributed to the construct of interest (Fornell and Larcker, 1981). The composite reliabilities, which ranged from .85 to .92 , each met the required level.

All tests of discriminant validity were supportive. That is, no confidence intervals of the correlations for the constructs $(\phi$ values) included $1.0(p<.05)$ (Anderson and Gerbing, 1988), and the square of the intercorrelations between two constructs, $\phi^{2}$ was less than the AVE estimates of the two constructs. This was true for all pairs of constructs (Fornell and Larcker, 1981). Inter-item correlations, Cronbach's alpha, composite reliabilities (CR), and AVE values are shown in Table 3.

\section{Structural Model}

The structural model was tested using maximum likelihood estimation. The structural model indicates an acceptable fit to the data $\left(\chi^{2}[.275]=445.2, p=.00\right.$; $\mathrm{CFI}=.91 ; \mathrm{TLI}=.90 ;$ and $\mathrm{RMSEA}=.064)$. Figure 2 presents the results from the structural model, indicating that four out of the six research hypotheses were supported.

\section{Results}

The results show a significant positive relationship between supplier responsibility and supplier development ( $\beta=.23, p<.01$ ), providing support for $\mathrm{H} 1$. However, $\mathrm{H} 2$ is not supported, with results indicating that skills similarity is not significantly associated with supplier development $(\beta=.09, p=\mathrm{NS})$, while contrary to expectations in $\mathrm{H} 3$, single supplier is significantly negatively related to supplier development $(\beta=-.19, p<.05)$. SD-NPD is positively related to supplier task performance $(\beta=.20$, $p<.05)(\mathrm{H} 4)$, and in turn, supplier task performance was shown to have a significant positive impact on new product advantage $(\beta=.31, p<.001)$ and project performance $(\beta=.36, p<.001)$ providing support for $\mathrm{H} 5$ and H6, respectively.

A nested model was also used to identify the presence of direct effects between supplier task performance and 
Table 3. Descriptive Statistics

\begin{tabular}{|c|c|c|c|c|c|c|c|c|c|c|}
\hline Variable $e^{a, b}$ & 1. & 2. & 3. & 4. & 5. & 6. & 7. & 8. & 9. & 10. \\
\hline 1. New product advantage & .84 & & & & & & & & & \\
\hline 2. Project performance & .23 & .83 & & & & & & & & \\
\hline 3. Supplier task performance & .29 & .30 & .88 & & & & & & & \\
\hline 4. Supplier development in NPD & .11 & .07 & .17 & .86 & & & & & & \\
\hline 5. Skills similarity & .06 & .20 & .12 & .17 & .87 & & & & & \\
\hline 6. Supplier responsibility & -.10 & -.20 & .15 & .10 & -.05 & - & & & & \\
\hline 7. Single supplier sourcing & .13 & .02 & -.02 & -.13 & -.21 & .01 & - & & & \\
\hline 8. Relationship length & .15 & .05 & .09 & .13 & .11 & -.19 & -.06 & - & & \\
\hline 9. Component importance & .26 & -.01 & .02 & .16 & -.04 & .03 & .12 & -.06 & - & \\
\hline 10. Technological newness & .25 & -.08 & .02 & .05 & -.14 & -.23 & .09 & .07 & .15 & - \\
\hline Mean & 5.42 & 5.02 & 4.35 & 4.17 & 3.50 & 0.30 & 0.59 & 79.62 & 0.42 & 0.59 \\
\hline Standard deviation & 1.42 & 1.01 & 1.24 & 1.55 & 1.62 & 0.28 & 0.49 & 69.44 & 0.50 & 0.49 \\
\hline Average Variance Extracted & 0.79 & 0.59 & 0.65 & 0.61 & 0.62 & - & - & - & - & - \\
\hline Compositie Reliability & 0.92 & 0.85 & 0.92 & 0.86 & 0.87 & - & - & - & - & - \\
\hline
\end{tabular}

${ }^{\text {a }}$ For $N=153, r$ has to be 0.161 or higher to be significant $(p<0.05)$.

${ }^{\mathrm{b}}$ Cronbach's alpha shown in bold on the diagonal.

new product advantage and project performance. Results indicate that each direct effect was nonsignificant, and a chi-square difference test against the hypothesized model showed no significant improvement in model fit to new product advantage $\left(\Delta \chi^{2}[1]=.04, \mathrm{NS}\right)$ or project performance $\left(\Delta \chi^{2}[1]=.10, \mathrm{NS}\right)$. These results indicate that the hypothesized model is the most parsimonious representation of the data. A Sobel test (1982) further indicates

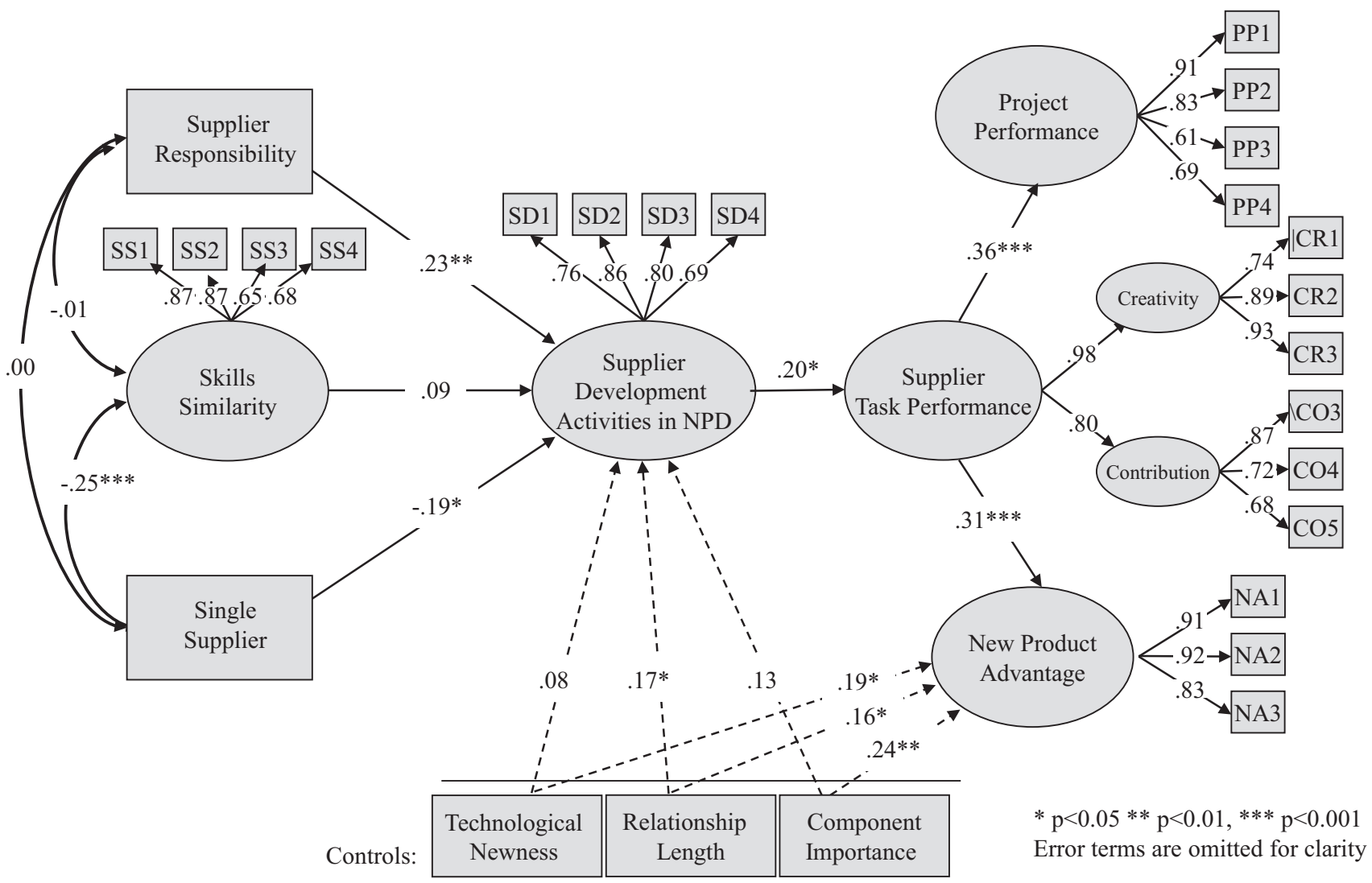

Figure 2. Structural Model 
that SD-NPD has a significant indirect effect on new product advantage $(t=1.66, p=.05)$, and project performance $(t=1.68, p=.05)$, operating through supplier task performance.

With regard to control variables, the results indicate that relationship length is positively related to SD-NPD $(\beta=.17, p<.05)$ and to new product advantage $(\beta=.16$, $p<.05)$. Technological newness of the firm's end product $(\beta=.08, p=\mathrm{NS})$ and component importance $(\beta=.13$, $p=\mathrm{NS}$ ) were both found to have no significant relation to SD-NPD but were significantly associated with new product advantage at $\beta=.19(p<.05)$ and $\beta=.24$ $(p<.01)$, respectively. In addition, the components of technological contribution and supplier creativity both loaded at high levels on the second-order supplier task performance factor. These loadings $(\beta=.80, p<.001$ and $\beta=.98, p<.001$, respectively) provide an indication of the relative contribution of the components to overall supplier task performance.

\section{Discussion}

Overall, the results of the study support the notion that companies' supplier development efforts during NPD can play an important role in instigating creativity and innovativeness in key suppliers, and ultimately enhance the performance of NPD projects. The results also provide support for Dyer and Singh's (1998) relational view, where knowledge-sharing routines and complementary resources and capabilities are among the sources of competitive advantage that span organizational boundaries. Further, a series of case study visits to companies, undertaken prior to administration of the survey research reported in this paper, also provided us with descriptions of the role of suppliers in NPD efforts. In virtually every project, there were problems, many of which originated from suppliers or interfaces with suppliers. These NPD experts talked about suppliers who lied about their NPD progress, about planned technologies that never made it into the new products, about missed NPD time deadlines and cost targets, and so on. In most cases, companies held debriefing sessions after their NPD projects, wherein they attempted to diagnose what had happened, both good and bad, and how to improve for the next NPD effort. Many of these improvements included the need to improve the customer-supplier interface, and to help suppliers improve the quality, delivery, and technical specifications of their NPD deliverables.

Consistent with H1, suppliers with greater responsibility for NPD activities, measured as the percentage of engineering hours contributed to the end product, were more likely to receive development and education practices from the buyer to upgrade their NPD capabilities. These findings are consistent with prior research where firms proactively implement supplier development with critical suppliers to maintain operational performance imperatives such as quality, delivery, and technological standards in their supply bases (Krause et al., 1998). However, our results indicate that managers should also consider designating resources for supplier development and education during NPD. While supplier development is a time and resource-intensive process, managers can act strategically by deciding to focus their supplier development on key suppliers of strategic items. The results of H1 further reinforce the importance of complementary resource endowments and distinctive resources brought by each party to NPD (Dyer and Singh, 1998). H1 proposed that suppliers making the most significant contributions to NPD were the most likely recipients of supplier development efforts. In such cases, a supplier may have significant engineering expertise but, for example, limited project management skills. Thus, a firm should be aware of their suppliers' abilities and limitations so as to decide when and where supplier development should occur.

$\mathrm{H} 2$ proposed that a firm would be less likely to invest in SD-NPD as buyer-supplier skills increasingly overlap. H2 was justified through Dyer and Singh's (1998) notion that competitive advantage was most likely to result from relationships where the parties brought complementary resource endowments, that is, distinctive resources that when combined, yielded relational rent (Mesquita et al., 2008). However, we did not find support for this relationship. A possible explanation for the insignificant finding is that the relationship between skills similarity and supplier development is highly context specific to different collaborative NPD projects. For some NPD projects, similar pools of knowledge between firm and supplier facilitate the sharing of R\&D and technological know-how necessary for successful performance, and supplier development is not required as the supplier already meets or exceeds the firm's technological standards. For other projects, firms may involve suppliers with a different set of technical skills and use supplier development to align the supplier's technological capabilities and product development routines to their needs (Wagner and Krause, 2009). Moreover, there may be suppliers that are niche technological providers that do not require development by the firm because they are already technical leaders in their specific field (Prahalad and Hamel, 1990). Our sample may include NPD projects that fall into each of these 
scenarios, thus emphasizing the need for future research to explore the complex relationships between skills similarity and supplier development in NPD.

Previous research suggests that firms focus their development efforts on single suppliers due to the risks arising from their monopoly position, technological lockin, path dependency, and limited competition (Deming, 1986; Richardson and Roumasset, 1995). Contrary to expectations, our results in testing $\mathrm{H} 3$ indicated a significant but negative relationship between a single-sourcing strategy and the level of supplier development. A number of factors may help explain this counter-intuitive finding. First, firms are likely to implement a more intensive supplier selection and monitoring process with their single suppliers in comparison to multiple suppliers (Ramsay, 1990). Consequently, the single suppliers selected for involvement in NPD are less likely to require further technological development from the firm. Second, the supplier may be a technological leader within the supplier market, and have developed a new component that competitors find difficult to imitate (Barney, 1991). These suppliers are likely to have established technological capabilities and also do not require the firm to develop their NPD capabilities. Single suppliers with a firstmover advantage may also be less receptive to supplier development efforts undertaken by firms for fear of knowledge leakages to rivals, the erosion of their bargaining power, or the firm acting opportunistically (Costantino and Pellegrino, 2010).

Attention now turns to the impact of supplier development on NPD performance outcomes, and our analysis of the bilateral exchange between supplier development efforts by the firm and the supplier's reciprocal contribution to the NPD project. Our results indicate that supplier development during NPD results in improved supplier task performance, in terms of the creativity of the supplier solution and its potential technological contribution to the buyer firm's end product (H4). Improved supplier creativity and innovation is a key motivation for involving suppliers in NPD, and our results show that engaging in supplier development activities is an effective route to achieving this goal. Consistent with the literature on creativity (e.g., Amabile, Conti, Coon, Lazenby, and Herron, 1996), the results of the present study suggest that supplier development activities serve to increase the stock of new knowledge and routinebuilding within the supplier's NPD function, facilitating, among others, the ability to generate creative solutions to technical problems. This idiosyncratic knowledge transferred from buyer to supplier may range from component and architectural knowledge, to technical and managerial know-how required to boost creativity and innovation (Modi and Mabert, 2006).

Support for the positive relationships between supplier task performance and both project performance (H5) and new product advantage (H6) was found. The results support the existence of a significant, positive indirect effect on both project performance and new product advantage, operating through supplier task performance. In other words, firms are able to appropriate relational rents in the form of improved project performance (ontime, to budget, meeting required technical objectives) and product performance (market advantage) when they focus development efforts on enhancing their supplier's creativity and technological contributions to NPD (Dyer and Singh, 1998).

Overall, our results point to the importance of relationship-specific, bilateral exchanges as a source of competitive advantage. Investments in upgrading a supplier's NPD capabilities do not specifically influence typical NPD performance metrics related to project or product performance. However, the returns from their development efforts arise indirectly through access to more technologically savvy suppliers who are better able to undertake creative problem-solving activities and contribute valuable technology to the buyer. These results hold after controlling for the influence of component importance, length of the relationship, and technological newness of the end product on both the extent of supplier development and education activities, as well as the new product advantage achieved, relative to competitors. Thus, our results illustrate the value derived from investing in supplier development during NPD, as a partnerspecific routine, which leads to gains deployable only within the relationship.

\section{Managerial Implications}

One of the primary managerial recommendations from this study is to recognize the potential contribution that supplier development can make in NPD, and to extend traditional supplier development programs to focus proactively on developing suppliers that are chosen for involvement in NPD. This effort may include adapting supplier development goals, programs, and initiatives undertaken by the firm with a greater emphasis given to developing the supplier's creativity and technological capabilities (Wagner and Krause, 2009). For larger firms, these efforts may also require the formation of dedicated cross-functional teams to manage the development and involvement of suppliers throughout the NPD project. Our findings highlight the importance of considering pro- 
active supplier development before, during, and after suppliers are involved in NPD, especially with regards to key suppliers with greater design responsibility.

Toyota serves as an example of a company that has recently emphasized the use of a single supplier strategy for many of its component parts (Economist, 2010). Spurred on by an effort to increase its market share, the company integrated many of these suppliers into its NPD projects. However, transparency of these suppliers' actions and capabilities apparently slipped as the company's monitoring efforts lagged behind its dramatic growth. Ironically, Toyota has clearly documented supplier development capabilities (Liker and Choi, 2004). Better monitoring of these suppliers might have identified the need for supplier development as an important concurrent activity to the involvement of these suppliers in the various NPD projects.

Our results also indicate a need to reexamine the metrics against which supplier development programs are assessed. Operational performance criteria typically used to evaluate such programs (e.g., lead times, cost savings, schedule targets, quality defects) are unlikely to detect the beneficial impact of supplier development activities on supplier creativity and technological contribution within interorganizational NPD projects. However, we encourage managers to broaden their perspective, recognizing that investments in building a supplier's NPD capabilities will ultimately be reflected in improved product and project performance, and reflect relationalspecific rents unavailable to competitors.

\section{Limitations and Future Research}

A number of limitations should to be taken into consideration when interpreting the results from this study. First, although our study focuses on cross-sectional data collected from a large sample of industries, it is based upon firms within the United Kingdom manufacturing sector, which may limit generalizability. The practicalities of collecting detailed data on a single key supplier involved in a single NPD project limited the size of our sample and meant that many contingent factors could not be examined in detail. In addition, case study research could help identify how firms synchronize their supplier development programs and supplier involvement initiatives over time and how the relational rents from supplier development are shared between the two parties. Moreover, future research efforts could include the collection of data from multiple respondents on both sides of the dyadic relationship (Nyaga, Whipple, and Lynch, 2010).
Broadly speaking, our results lend support for Dyer and Singh's (1998) relational view of the firm by illustrating that the sources of value, in part, lie in the relationships between firms (Mesquita et al., 2008). Building on Dyer and Singh (1998), future research could explore each of the four potential sources of value or relational rent. For example, researchers might examine the value of different interfirm relationship-specific assets to NPD, which may be site, physical asset, or human asset specific (Williamson, 1985). Further, researchers could examine the timing and nature of supplier development in NPD, as well as investigate the enablers, barriers, and complexities of two-way knowledge sharing during collaborative NPD.

The outcomes of NPD, as measured in the present study, point to greater relational rents obtained by collaborative supplier development and involvement in the NPD project. Future research could explore the extent to which these gains are captured by the buyer-supplier dyad, or are also potentially redeployable by the supplier to other customers as a form of market spillover. Finally, while the present study did not include measures of governance, which includes formal safeguards (such as legal contracts) and informal safeguards (such as trust or embeddedness), future research could explore which governance mechanisms foster supplier development in NPD, and how firms can successfully develop their suppliers' creativity and technological contributions.

\section{Conclusion}

We proposed a theoretical model to investigate the antecedents and consequences of supplier development in interorganizational NPD projects. We consider the bilateral interactions that occur between firms and their suppliers, with supplier development primarily representing a flow of information and resources toward the supplier, and supplier involvement in NPD representing a flow of information and technology toward the firm. In addition, where previous studies of supplier development have framed the benefits primarily in terms of operational performance improvements, we show that supplier development influences firm NPD outcomes indirectly via improvements in a supplier's creative problem-solving capabilities. In other words, firms appropriate relational rents from their supplier development activities by integrating their supplier's creative ideas and new technologies into their NPD projects. Overall, these findings provide managers and academics with evidence of the importance of developing suppliers' creative and innovative capabilities to improve the performance of 
interorganizational NPD. Our findings may also provide clues about underlying reasons for many companies' suboptimal experiences in NPD projects, and we hope our study incites further research in this area.

\section{References}

Amabile, T. M. 1998. How to kill creativity. Harvard Business Review 76 (5): 76-87.

Amabile, T. M., R. Conti, H. Coon, J. Lazenby, and M. Herron. 1996. Assessing the work environment for creativity. Academy of Management Journal 39 (5): 1154-84.

Anderson, J. C., and D. W. Gerbing. 1988. Structural equation modeling in practice: A review and recommended two-step approach. Psychological Bulletin 103: 411-23.

Armstrong, S. J., and T. S. Overton. 1977. Estimating non-response bias in mail surveys. Journal of Marketing Research 14 (3): 396-402.

Bagozzi, R. P., and Y. Yi. 1988. On the evaluation of structural models. Journal of the Academy of Marketing Science 16 (1): 74-94.

Barney, J. 1991. Firm resources and sustained competitive advantage. Journal of Management 17 (1): 99-120.

Bensaou, M., and E. Anderson. 1999. Buyer-supplier relations in industrial markets: When do buyers risk making idiosyncratic investments? Organization Science 10 (4): 460-81.

Bonaccorsi, A., and A. Lipparini. 1994. Strategic partnerships in new product development: An Italian case study. Journal of Product Innovation Management 11 (2): 134-45.

Carson, S. J. 2007. When to give up control of outsourced new product development. Journal of Marketing 71 (1): 49-66.

Clark, K. B., and T. Fujimoto. 1991. Product development performance. Boston, MA: Harvard Business School Press.

Clark, N. 2006. The Airbus saga: Crossed wires and a multibillion-euro delay. International Herald Tribune. Dec 11.

Costantino, N., and R. Pellegrino. 2010. Choosing between single and multiple sourcing based on supplier default risk: A real options approach. Journal of Purchasing and Supply Management 16 (1): 27-40.

Day, G. S. 1994. The capabilities of market-driven organizations. Journal of Marketing 58 (4): 37-53.

Deming, W. E. 1986. Out of crisis. Cambridge, MA: MIT Center for Advanced Engineering Study.

Dillman, D. A. 2000. Mail and Internet surveys: The tailored design method (2nd ed.). New York: John Wiley.

Dyer, J. H., and N. W. Hatch. 2006. Relation-specific capabilities and barriers to knowledge transfers: Creating advantage through network relationships. Strategic Management Journal 27: 701-19.

Dyer, J. H., and W. G. Ouchi. 1993. Japanese-style partnerships: Giving companies a competitive edge. Sloan Management Review 35 (1): 51-63.

Dyer, J. H., and H. Singh. 1998. The relational view: Cooperative strategy and sources of interorganizational competitive advantage. Academy of Management Review 23 (4): 660-79.

Economist. 2010. Toyota's overstretched supply chain: The machine that ran too hot. The Economist. Feb 24.

Eisenhardt, K. M., and B. N. Tabrizi. 1995. Accelerating adaptive processes: Product innovation in the global computer industry. Administrative Science Quarterly 40: 84-110.

Emden, Z., R. Calantone, and C. Droge. 2006. Collaborating for new product development: Selecting the partner with maximum potential to create value. Journal of Product Innovation Management 23 (4): 33041.
Fornell, C., and D. F. Larcker. 1981. Evaluating structural equation models with unobservable variables and measurement error. Journal of Marketing Research 18 (1): 39-50.

Forza, C. 2002. Survey research in operations management: A processbased perspective. International Journal of Operations \& Production Management 22 (2): 152-94.

Gerbing, D. W., and J. C. Anderson. 1992. Monte Carlo evaluations of goodness of fit indices for structural equation models. Sociological Methods and Research 21 (2): 132-60.

Grant, R. M. 1996. Prospering in dynamically-competitive environments: Organizational capability as knowledge integration. Organization Science 7 (4): 375-87.

Greene, W. H. 2002. Econometric analysis (5th ed.). Upper Saddle River, NJ: Prentice Hall.

Hair, J. F., R. E. Anderson, R. L. Tatham, and W. C. Black. 1998. Multivariate data analysis (5th ed.). Upper Saddle River, NJ: Prentice-Hall.

Handfield, R. B., G. L. Ragatz, K. J. Petersen, and R. M. Monczka. 1999. Involving suppliers in new product development. California Management Review 42 (1): 59-82.

Hartley, J. L., and T. Y. Choi. 1996. Supplier development: Customers as a catalyst of process change. Business Horizons 39 (4): 37-44.

Hartley, J. L., J. R. Meredith, D. McCutcheon, and R. R. Kamath. 1997. Suppliers' contributions to product development: An exploratory study. IEEE Transactions on Engineering Management 44 (3): 258-67.

Hoopes, D. G. 2001. Why are there glitches in product development? $R \& D$ Management 31 (4): 381-89.

Hoopes, D. G., and S. Postrel. 1999. Shared knowledge, "glitches," and product development performance. Strategic Management Journal 20: 837-65.

Jarratt, D. G. 2004. Conceptualizing a relationship management capability. Marketing Theory 4: 287-309.

Johnsen, T. E. 2009. Supplier involvement in new product development and innovation: Taking stock and looking to the future. Journal of Purchasing and Supply Management 15 (3): 187-97.

King, B. E., and R. J. Penleskey. 1992. Impediments to timely delivery of new products at an industrial product firm. International Journal of Operations \& Production Management 12: 56-65.

Kotabe, M., X. Martin, and H. Domoto. 2003. Gaining from vertical partnerships: Knowledge transfer, relationship duration, and supplier performance improvement in the U.S. and Japanese automotive industries. Strategic Management Journal 24 (4): 293-316.

Koufteros, X. A., G. E. Rawski, and R. Rupak. 2010. Organizational integration for product development: The effects on glitches, on-time execution of engineering change orders, and market success. Decision Sciences 41 (1): 49-80.

Krause, D. R. 1999. The antecedents of buying firms' efforts to improve suppliers. Journal of Operations Management 17 (2): 205-24.

Krause, D. R., R. B. Handfield, and T. V. Scannell. 1998. An empirical investigation of supplier development: Reactive and strategic processes. Journal of Operations Management 17 (1): 39-58.

Krause, D. R., R. B. Handfield, and B. B. Tyler. 2007. The relationships between supplier development, commitment, social capital accumulation and performance improvement. Journal of Operations Management 25 (2): 528-45.

Krause, D. R., T. V. Scannell, and R. J. Calantone. 2000. A structural analysis of the effectiveness of buying firms' strategies to improve supplier performance. Decision Sciences 31 (1): 33-55.

Lau, A. K. W., E. Tang, and R. C. M. Yam. 2010. Effects of supplier and customer integration on product innovation and performance: Empirical evidence in Hong Kong manufacturers. Journal of Product Innovation Management 27 (5): 761-77.

Lawson, B., K. J. Petersen, P. D. Cousins, and R. B. Handfield. 2009. Knowledge sharing in interorganizational product development teams: The effect of formal and informal socialization mechanisms. Journal of Product Innovation Management 26 (2): 156-72. 
Lawson, B., and A. Potter. 2012. Determinants of knowledge transfer in inter-firm new product development projects. International Journal of Operations \& Production Management 32 (10): 1228-47.

Lawson, B., B. B. Tyler, and A. Potter. 2014. Strategic suppliers' technical contributions to new product advantage: substitution and configuration options. Journal of Product Innovation Management doi:10.1111/ jpim. 12235 .

Leenders, M. R. 1966. Supplier development. Journal of Purchasing 2 (4): 47-62.

Leonard-Barton, D. 1995. Wellsprings of knowledge: Building and sustaining the sources of innovation. Boston, MA: Harvard Business School Press.

Lieberman, M. B., and D. B. Montgomery. 1988. First-mover advantages. Strategic Management Journal 9 (Special Issue: Strategy Content Research): 41-58.

Liker, J. K., and T. Y. Choi. 2004. Building deep supplier relationships. Harvard Business Review: 104-13.

Liker, J. K., R. R. Kamath, and S. N. Wasti. 1998. Supplier involvement in design: A comparative survey of automotive suppliers in the USA, UK and Japan. International Journal of Quality Science 3 (3): 214-38.

Liker, J. K., R. R. Kamath, S. N. Wasti, and M. Nagamachi. 1996. Supplier involvement in automotive component design: Are there really large US Japan differences? Research Policy 25: 59-89.

Littler, D., F. Leverick, and M. Bruce. 1995. Factors affecting the process of collaborative product development: A study of UK manufacturers of information and communications technology products. Journal of Product Innovation Management 12 (1): 16-32.

Loch, C. H., and S. Kavadias. 2008. Handbook of new product development management. Burlington, MA: Butterworth Heinemann-Elsevier.

Mesquita, L. F., J. Anand, and T. H. Brush. 2008. Comparing the resourcebased and relational views: Knowledge transfer and spillover in vertical alliances. Strategic Management Journal 29 (9): 913-41.

Modi, S. B., and V. A. Mabert. 2006. Supplier development: Improving supplier performance through knowledge transfer. Journal of Operations Management 25 (1): 42-64.

Nyaga, G. N., J. M. Whipple, and D. F. Lynch. 2010. Examining supply chain relationships: Do buyer and supplier perspectives on collaborative relationships differ? Journal of Operations Management 28 (2): 101-14.

Petersen, K. J., R. B. Handfield, and G. L. Ragatz. 2003. A model of supplier integration into new product development. Journal of Product Innovation Management 20 (4): 284-99.

Petersen, K. J., R. B. Handfield, and G. L. Ragatz. 2005. Supplier integration into new product development: Coordinating product, process and supply chain design. Journal of Operations Management 23 (4): 37188.

Podsakoff, P. M., S. B. MacKenzie, J. Y. Lee, and N. P. Podsakoff. 2003. Common method biases in behavioral research: A critical review of the literature and recommended remedies. Journal of Applied Psychology 88: 879-903.

Potter, A., and B. Lawson. 2013. Help or hindrance? Causal ambiguity and supplier involvement in new product development teams. Journal of Product Innovation Management 30 (4): 794-808.

Prahalad, C. K., and G. Hamel. 1990. The core competencies of the corporation. Harvard Business Review 68 (3): 79-91.

Primo, M. A. M., and S. D. Amundson. 2002. An exploratory study of the effects of supplier relationships on new product development outcomes. Journal of Operations Management 20 (1): 33-52.

Ragatz, G. L., R. B. Handfield, and T. V. Scannell. 1997. Success factors for integrating suppliers into new product development. Journal of Product Innovation Management 14 (3): 190-202.

Ramsay, J. 1990. The myth of the cooperative single source. International Journal of Purchasing and Materials Management 26 (1): 2-5.

Rauniar, R., W. J. Doll, G. E. Rawskic, and P. Hong. 2008. Shared knowledge and product design glitches in integrated product development. International Journal of Production Economics 114 (2): 723-36.
Richardson, J., and J. Roumasset. 1995. Sole sourcing, competitive sourcing, parallel sourcing: Mechanism for supplier performance. Managerial and Decision Economics 16 (1): 71-84.

Roy, S., and K. Sivakumar. 2012. Global outsourcing relationships and innovation: A conceptual framework and research propositions. Journal of Product Innovation Management 29 (4): 513-30.

Seltzer, L. 1928. A financial history of the American automobile industry. Boston: The Riverside Press.

Sobel, M. E. 1982. Asymptotic confidence intervals for indirect effects in structural equations models. In Sociological methodology, ed. S. Leinhart, 290-312. San Francisco, CA: Jossey-Bass.

Sobrero, M., and E. B. Roberts. 2002. Strategic management of suppliermanufacturer relations in new product development. Research Policy 31: $159-82$.

Song, M., and C. A. Di Benedetto. 2008. Supplier's involvement and success of radical new product development in new ventures. Journal of Operations Management 26 (1): 1-22.

Song, M., and M. E. Parry. 1997. The determinants of Japanese new product successes. Journal of Marketing Research 34 (1): 64-76.

Swink, M. 1999. Threats to new product manufacturability and the effects of development team integration processes. Journal of Operations Management 17 (6): 691-709.

Takeishi, A. 2001. Bridging inter- and intra-firm boundaries: Management of supplier involvement in automobile product development. Strategic Management Journal 22: 403-33.

Tang, C. S., and J. D. Zimmerman. 2009. Managing new product development and supply chain risks: The Boeing 787 case. Supply Chain Forum: An International Journal 10 (2): 74-85.

Van Echtelt, F. E. A., F. Wynstra, A. J. Van Weele, and G. Duysters. 2008. Managing supplier involvement in new product development: A multiple-case study. Journal of Product Innovation Management 25 (2): 180-201.

von Corswant, F., and P. Fredriksson. 2002. Sourcing trends in the car industry: A survey of car manufacturers' and suppliers' strategies and relations. International Journal of Operations \& Production Management 22 (7): 741-58.

Wagner, S. M. 2006. Supplier development practices: An exploratory study. European Journal of Marketing 40 (5/6): 554-71.

Wagner, S. M., and D. R. Krause. 2009. Supplier development: Communication approaches, activities and goals. International Journal of Production Research 47 (2): 3161-77.

Williamson, O. E. 1985. The economic institutions of capitalism: Firms, markets, relational contracting. New York: Free Press.

Wynstra, F., F. von Corswant, and M. Wetzels. 2010. In chains? An empirical study of antecedents of supplier product development activity in the automotive industry. Journal of Product Innovation Management 27 (5): 625-39.

\section{Appendix. Constructs and Items}

\section{New Product Advantage}

NA1: Offered unique features or attributes to the customer

NA2: Was clearly superior in terms of meeting customers' needs

NA3: Had superior technical performance

NA4: Offered higher quality - tighter specs, stronger, lasted longer, or more reliable ${ }^{\mathrm{a}}$

NA5: Permitted the customer to do a job or do something he could not presently do ${ }^{\mathrm{a}}$ 


\section{Project Performance}

PP1: Met quality standards

PP2: Met technical objectives

PP3: Achieved schedule targets

PP4: Achieved project goals

PP5: Budgeted cost targets ${ }^{\mathrm{a}}$

\section{Supplier Task Performance}

CR1: The supplier exhibited a great deal of creativity in its work

CR2: The supplier's technology incorporated a great deal of new knowledge and discovery

CR3: The supplier's technology was very innovative

CO4: The technology will contribute a great deal to the competitiveness of our products

CO5: The technology will contribute a great deal to the functionality of our products

CO6: The technology will contribute a great deal to the profitability of our products

\section{Supplier Development Activities in New Product Development ( $S D-N P D)$}

SD1: We were directly involved in this supplier's product development activities

SD2: We used site visits to this supplier's premises to help improve their product development performance
SD3: We aided in the design of production processes for this supplier's new item

SD4: We provided project management know-how to this supplier during product development

SD5: We provided technological know-how to this supplier during product development ${ }^{\mathrm{a}}$

\section{Skills Similarity}

SS1: The supplier's technical work was very similar to work regularly done throughout our firm

SS2: The technical work for our most important products is very similar to the work the supplier was doing

SS3: Most people in our firm had the same training and technical background as the supplier's people on the project

SS4: Our firm was known for successful performance of the type of work the supplier was doing

\section{Supplier Responsibility}

Approximately, what percent of the total engineering hours for your end product were attributable to this specific supplier?

\section{Single Supplier Sourcing}

How many suppliers were involved in the design of this component on the project?

${ }^{a}$ Item was dropped during scale purification. 